\title{
Water Security in China's Neighboring Diplomacy
}

\section{Li Zhifei}

\begin{abstract}
Water security has become one of the most important topics in China's relations with neighboring countries. Currently, there is an asymmetric interdependence and a structure of "low conflict and low cooperation" between China and neighboring countries, which leads to a sense of insecurity over the water resource utilization. Consequently, some of these countries are trying to form a potentially strategic alliance with other countries outside the region to contain China's "water power," which will exert negative impact on China's relationship with these neighboring countries and change the overall security environment on China's peripheries. In the future, however, China's strategic advantage on water resources could serve as the basis of diplomatic breakthroughs to promote regional water governance in alignment with China's national interest. China should take advantage of its strategic position as the "Water Tower in Asia" to formulate a water resource security strategy, establish feasible sharing and compensation mechanisms, and create new arenas for its neighboring diplomacy.
\end{abstract}

Li Zhifei is a post-doctoral researcher at the School of International Studies, Peking University, and Associate Researcher at the National Institute of International Strategy (NIIS), Chinese Academy of Social Sciences (CASS). She can be reached at Lizf@cass.org.cn.

(c) 2015 World Century Publishing Corporation and Shanghai Institutes for International Studies China Quarterly of International Strategic Studies, Vol. 1, No. 4, 625-646 
Keywords: Water security; water power; alliance; China's neighboring diplomacy.

\section{Water Security: An Emerging Topic in China's Neighboring Diplomacy}

Being scarce and strategic in nature, water as a resource is one of the few necessities for human survival and development. Since China shares with its neighboring countries more than 80 trans-boundary rivers that affect three billion people, nearly half of the global population, water security has emerged as one of the most significant topics in China's neighboring diplomacy.

Some Western scholars have conducted pilot research on water security issues between China and its neighboring countries. These scholars usually hold negative attitudes toward China, which are influenced by media commentaries. They accuse China of using its geographical advantage to maximize its own development interests while ignoring other countries' rights of water utilization. China and its neighboring countries are always in rivalry and competition when dealing with trans-boundary water issues, whilst downstream countries are facing security threats with regard to issues such as water utilization, ecology, environment, and economic development, amongst others. ${ }^{1}$

While water security on China's peripheries deserves wide attention in terms of political, economic, environmental, and security dimensions,

\footnotetext{
${ }^{1}$ Marwaan Macan Markar, Asia: Dam Across the Mekong Could Trigger a Water War (New York: Global Information Network, 2009); Milton Osborne, River at Risk: the Mekong and the Water Politics of Southeast Asia (Double Bay, N.S.W.: Longueville Media, 2004); Alex Liebman, "Trickle-down Hegemony? China's 'Peaceful Rise' and Dam Building on the Mekong," Contemporary Southeast Asia, Vol. 27, No. 2 (August 2005), pp. 281-304; Timo Menniken, "China's Performance in International Resource Politics: Lesson from the Mekong," Contemporary Southeast Asia, Vol. 29, No. 1 (April 2007), pp. 97-120; Philip Hirsch and Kurt Morck Jensen, "National Interests and Transboundary Water Governance in the Mekong," University of Sydney website, http://sydney.edu.au/mekong/documents/mekwatgov_mainreport.pdf; and Olive Hensengerth, "Trans-boundary River Cooperation and the Regional Public Good: The Case of the Mekong River," Contemporary Southeast Asia, Vol. 21, No. 2 (August 2009), pp. 326-349.
} 
it has received little interest from Chinese scholars. Admittedly, the geopolitical environment on China's peripheries is increasingly complicated, with ever growing impact from climate change. Most of China's peripheral countries are vulnerable to climate change, which could undermine the security of China as well as its neighboring countries. Since water is one of the linkages between China and its neighboring countries, it is of great significance to explore the approaches of water governance on China's peripheries for the mutual benefit of China and its neighboring countries.

\section{Current Disputes and Cooperation on Water Resources}

Water security is an indispensable part of national security and the strategic foundation of national economic development. Water security for a country means that its national sovereignty, national interests, and national development should not be undermined by water issues. ${ }^{2}$ Water issues usually cover many aspects such as water quality, water allocation, flood control, hydroelectricity, infrastructure and cooperative management, amongst others. In terms of their significance, water allocation accounts for 45 percent; infrastructure accounts for 19 percent; cooperative management accounts for 12 percent; hydroelectricity accounts for 10 percent; and water resource quality accounts for 6 percent. $^{3}$

Water-resource

disputes have increasingly become

a salient issue in

China's peripheral relations.

From a macroscopic view, China's relationships with neighboring countries regarding water security encompass both conflict and cooperation. The conflict on water security arises when two or more countries have different views or policies with regard to water development, utilization, management, and protection, sometimes with obvious contradiction or potential competition. The nature of conflict is

\footnotetext{
${ }^{2}$ Chang Mingqi and Huang Qiang, Shuiziyuan Anquan Lilun yu Fangfa [Water Resource Theory and Methods] (Beijing: China Water and Power Press, 2006), pp. 31-43.

${ }^{3}$ Aaron T. Wolf, Shira B. Yoffe, and Mark Giordano, "International Water: Identifying Basins at Risk," Water Policy, Vol. 5, No. 1 (January 2003), p. 41.
} 
complicated and usually caused by the incompatibility between related countries in economy, society, politics, law, organization, technology, culture, the environment, and history. ${ }^{4}$ The cooperation on water security mainly refers to the fair, rational, and effective use of water resources between countries with strategic considerations and relevant rules, laws, mechanisms on water utilization within a necessary and rational scope.

The patterns and intensity of conflict and cooperation are usually different in international relations. With geopolitical influence, achieving water security presents multi-level and intersecting characteristics. U.S. scholars, Shira Yoffe, Aaron. T. Wolf and Mark Giordano designed a risk evaluation program named "the Basin at Risk." In this program, there are 15 different types of conflict and cooperation: 0 refers to neutral, non-significant acts; -7 refers to formal war; -6 refers to extensive military conflict; -5 refers to small scale military conflict; -4 refers to political/military hostile acts; -3 refers to diplomatic/economic hostile acts; -2 refers to strong/official verbal hostility; -1 refers to mild/unofficial verbal hostility; 1 refers to mild verbal support; 2 refers to official verbal support; 3 refers to cultural, scientific agreement/support; 4 refers to non-military economic, technical, industrial agreement; 5 refers to military, financial, strategic support; 6 refers to international water treaty; 7 refers to unification into one nation. The historical realities show that there exist bilateral conflicts from -3 to -7 , while from +3 to +7 , there is multilateral cooperation. According to statistics, about 57 percent of the cooperation on water security falls into the scope from 0 to +1 which translates to a verbal support for cooperation. $^{5}$

Turning conflict into cooperation on water security will not be achieved once and for all because conflict and cooperation coexist in many cases. In a globalized era, it is difficult to use a single word - whether conflict or cooperation - to describe the relationship on water security between two countries. According to the degree of coexistence of

${ }^{4} \mathrm{Hu}$ Qinghe, “Liuyu Shuiziyuan Chongtu Jicheng Guanli Yanjiu [Study on Integrated Management of River Basin Water Resources Conflict]," PhD Dissertation, Hehai University, 2007, p. 40.

${ }^{5}$ Shira Yoffe, Aaron T. Wolf, and Mark Giordano, "Conflict and Cooperation over International Freshwater Resource: Indicator of Basin at Risk," Journal of the American Water Resource Association, Vol. 39, No. 5 (October 2003), p. 1113. 
conflict and cooperation, there are four basic structures: low-conflict and high-cooperation, low-conflict and moderate-cooperation, low-conflict and low-cooperation, and moderate/high conflict and low-cooperation (see Table 1).

Table 1. Structural Types of Conflict and Cooperation on Water Security.

\begin{tabular}{|c|c|c|c|}
\hline $\begin{array}{l}\text { Characterisation } \\
\text { of Interaction } \\
\text { nexus (TWINS) }\end{array}$ & Types of Interaction & $\begin{array}{l}\text { Example of Interac- } \\
\text { tion }\end{array}$ & $\begin{array}{l}\text { Potential Driving Forces } \\
\text { (non-exhaustive) }\end{array}$ \\
\hline $\begin{array}{l}\text { Low Conflict - } \\
\text { High Cooperation }\end{array}$ & $\begin{array}{l}\text { [positive interaction] } \\
\text { Cooperation on equal } \\
\text { terms; } \\
\text { Cooperation across a } \\
\text { broad range of issues; } \\
\text { Tensions reduces } \\
\text { through deliberative } \\
\text { processes }\end{array}$ & $\begin{array}{l}\text { Putting in place and } \\
\text { exercising principles } \\
\text { (i.e. equitable use, no } \\
\text { harm); } \\
\text { Creation of trans- } \\
\text { boundary regimes; } \\
\text { Negotiation of treaty } \\
\text { based on IWL; } \\
\text { Conclusion of an ef- } \\
\text { fective treaty (Kistin) }\end{array}$ & $\begin{array}{l}\text { Benefit sharing/expand- } \\
\text { ing the pie } \\
\text { Reduction of environ- } \\
\text { mental uncertainty }\end{array}$ \\
\hline $\begin{array}{l}\text { Low Conflict - } \\
\text { Med. Cooperation }\end{array}$ & $\begin{array}{l}\text { [neutral interaction] } \\
\text { Narrow cooperation } \\
\text { (cooperation on select } \\
\text { issues); Token cooper- } \\
\text { ation; Mild verbal ex- } \\
\text { pression of Conflict }\end{array}$ & $\begin{array}{l}\text { Joint pollution man- } \\
\text { agement; } \\
\text { Joint infrastructure; } \\
\text { Benefit sharing based } \\
\text { on agreements; } \\
\text { Creation of RBOs }\end{array}$ & $\begin{array}{l}\text { Economic/Developmen- } \\
\text { tal Goals } \\
\text { Issue linkage }\end{array}$ \\
\hline $\begin{array}{l}\text { Low Conflict - } \\
\text { Low Cooperation }\end{array}$ & $\begin{array}{l}\text { [neutral interaction] } \\
\text { Minimal or no inter- } \\
\text { action; Adhoc cooper- } \\
\text { ation; Self-interested } \\
\text { cooperation; Tactical } \\
\text { functional coopera- } \\
\text { tion; Unstable cooper- } \\
\text { ation }\end{array}$ & $\begin{array}{l}\text { Minor information } \\
\text { exchange; Technical } \\
\text { commissions or } \\
\text { meetings; }\end{array}$ & $\begin{array}{l}\text { Mutual distrust } \\
\text { Improvement of inter- } \\
\text { national reputation } \\
\text { Sharing of resources }\end{array}$ \\
\hline $\begin{array}{l}\text { Med/High Con- } \\
\text { flict — Low Co- } \\
\text { operation }\end{array}$ & $\begin{array}{l}\text { [negative interaction] } \\
\text { Securitised Conflict; } \\
\text { Coercive Cooperation; } \\
\text { Dominative Coopera- } \\
\text { tion; } \\
\text { Violent Conflict }\end{array}$ & $\begin{array}{l}\text { Contained conflict; } \\
\text { Negotiation of trea- } \\
\text { ties not based on } \\
\text { IWL; } \\
\text { Resource capture; } \\
\text { Unilateral environ- } \\
\text { mentalism (Fisch- } \\
\text { hendler) }\end{array}$ & $\begin{array}{l}\text { Changes in power sym- } \\
\text { metry } \\
\text { Control of resources }\end{array}$ \\
\hline
\end{tabular}

Source: Mark Zeitoun and Naho Mirumachi, “Trans-boundary Water Interaction: Reconsidering Conflict and Cooperation," International Environmental Agreement: Politics, Law and Economics, Vol. 8, No. 4 (2008), p. 310. 
Low-conflict and high-cooperation on water security is a positive structure or relationship that can meet basic needs of the basin countries and are beneficial to cooperation among these countries. The moderate/ high conflict and low-cooperation structure is a negative relationship in which countries concentrate on using power advantages to suppress conflict and launch dominant cooperation, which will not reduce the degree and the risk of conflict over water resource, but exert negative influence on the cooperation in other areas, thus triggering more severe conflicts among countries.

The neutral intersection structure includes two categories: namely low-conflict and moderate-cooperation, and low-conflict and lowcooperation. In these two categories, on one hand, the cooperation is unstable given its locality and strategic position which are based on temporary interests. On the other hand, the conflict in low degree or with low-possibility is the reason that chances of cooperation are always slim. In general, most of these conflicts are verbal and have not evolved into military or political conflicts. But with increasingly frequent utilization and fierce competition over water resources, the neutral intersection structure will gradually develop into a negative or positive structure, depending on how much political wisdom is exercised by the countries involved and how they decide to handle their differences.

The achievement of water security between China and its neighboring countries is closely related to water protection, water allocation and exploitation, water management, amongst other factors.

It can be seen from Table 2 that in North and Northeast Asia, the Yalu River, Heilongjiang River, and Ulungur River flow through several countries including China, Russia, Mongolia, and North Korea. The relationship of water security between China and Russia mainly focuses on the protection of

Tensions between

China and Southeast Asian countries are relatively higher due to their disputes on share of water, environmental protection and other means of utilization. water quality. For example, these two countries had disputes over the pollution of the Songhua River in 2005 when some Russian news media such as the Independent Newspaper and the Izvestia commented that China was threatening 


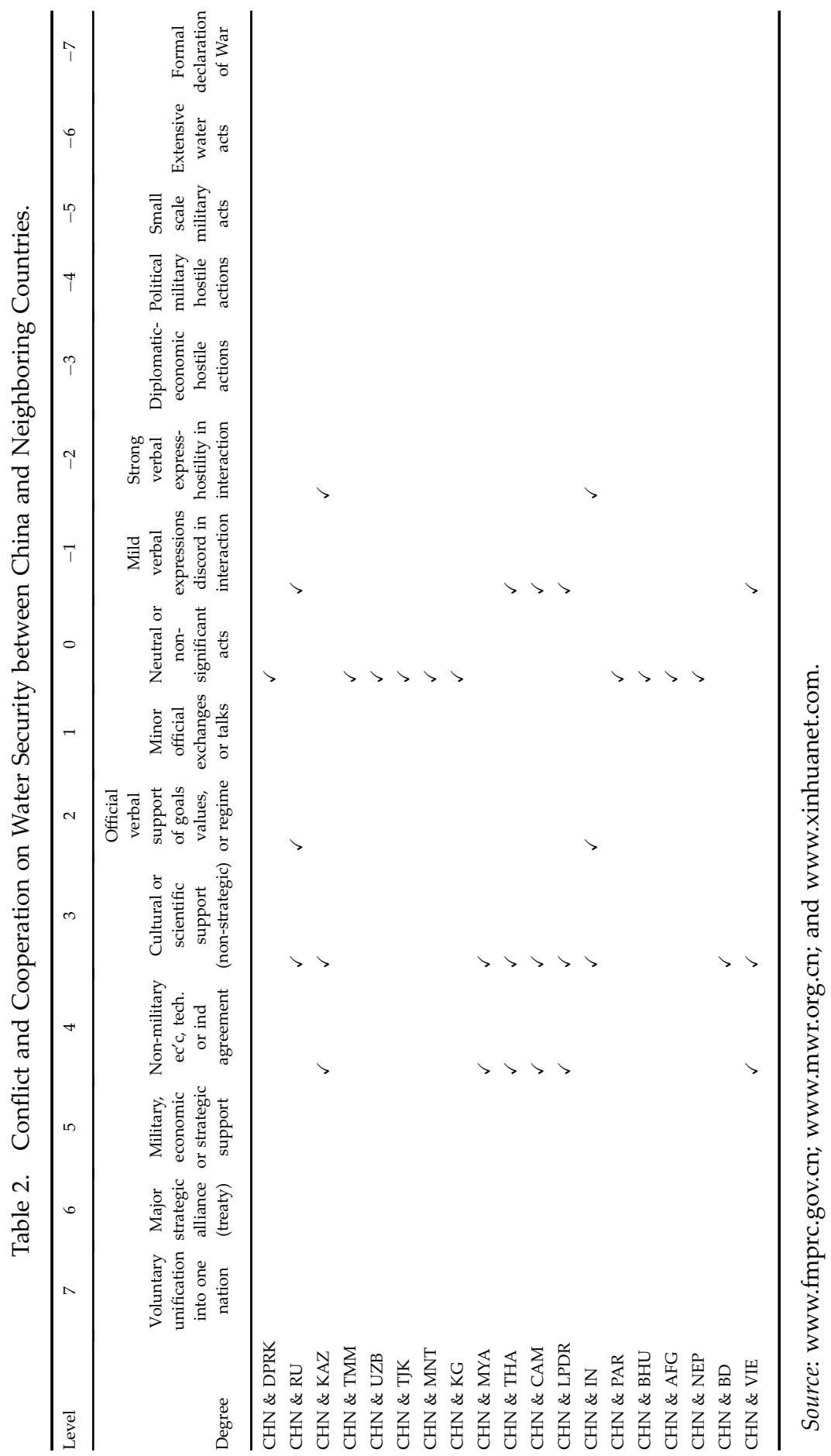


the water security of downstream countries. Eventually, disputes were solved through negotiations between the two governments and the "China and Russia Trans-boundary Water Quality Joint Monitoring Plan" was finalized in 2006 by which the water quality monitor and protection was taken as a priority for bilateral cooperation. In January 2008, China and Russia signed the "Trans-boundary Water Utilization and Protection Cooperation Agreement," which was the first agreement on water security between the two countries in history. This agreement enables China and Russia to jointly improve the ecology of the trans-boundary rivers and make definite rules for trans-boundary water utilization, protection and detection. In contrast, there seem to be no obvious disputes between China and Mongolia, or between China and North Korea, on water security. Therefore, their relationships in terms of water security are of a "non-significant nature."

In Central Asia, the allocation of trans-boundary water resources, especially those of the Ili River and Irtysh River, have created some obstacles for the further development of China-Kazakhstan relations. At the 2008 Shanghai Cooperation Organization (SCO) summit, the Kazak President advocated that China, as an upstream country, should not take water from the Ili River and Irtysh River in an unlimited manner. As a matter of fact, these two countries began their cooperation on water security in 2001 by signing the "Agreement for the Utilization and Protection of Transboundary Rivers" and setting up the Trans-boundary Rivers Utilization and Protection Committee. In 2008, this Committee was incorporated into the China-Kazakhstan Cooperation Committee. In their Joint Communiqués of 2001, 2006, 2007, 2008, 2010 and 2011, the topic of cooperation on water security has been included and well elaborated. In this light, the degree of water security cooperation between China and Kazakhstan is from +4 to -2 , while China's water security cooperation with Turkmenistan, Uzbekistan, Tajikistan, and Kyrgyzstan all present neutral status.

In Southeast Asia, there are also many trans-boundary rivers running through China and its neighboring countries. In 2003, many non-governmental organizations (NGOs) active in Southeast Asia resisted the exploitation of the $\mathrm{Nu}$ River in the name of ecological and environmental protection. In 2010, severe drought appeared in the Mekong River Basin, which motivated NGOs and the local media to condemn China's dam building on the upstream of the Lantsang River. At the same time, China's 
Ministry of Water Resources signed an agreement with the Mekong River Commission on Providing Flood Season Data, and also the "Agreement of Freedom of Navigation from Simao Gang to Luang Prabang" with Laos and Burma. Moreover, China has made large investments in Burma, Laos, Cambodia, Vietnam, and Thailand, constructing hydropower facilities and developing some trans-boundary rivers such as the Mekong River and the Irrawaddy River in cooperation with these countries. On the whole, the degree of China's water security cooperation with the five basin countries remains between +4 and -2 .

China's water security relationship with neighboring countries is generally characterized by low conflict and low cooperation.
In South Asia, the Yarlung ZangboBrahmaputra River, the Ganges River, and the Indus River connect China with India, Pakistan, Nepal, Bangladesh, Bhutan and Afghanistan respectively. In recent years, China and India have been frequently interacting on water security issues. For instance, China began to construct the Zangmu hydropower dam on the main stream of the Yarlung Zangbo River in 2010, and a large number of Indian researchers and media accused China of threatening India's national security. In January 2002, China and India signed the Memorandum of Understanding on China Providing Hydrological Data of Flood Season in Yarlung Zangbo-Brahmaputra River to India; in April of that year, the two countries signed the "Implementation Plan." In April 2005, China and India signed the Memorandum of Understanding on China Providing Hydrological Data of Flood Season in Sutlej River to India. In September 2008, China also signed with Bangladesh the Memorandum of Understanding on China Providing Hydrological Data of Flood Season in Yarlung Zangbo-Brahmaputra River to Bangladesh. The degree of water security cooperation between China and India lies between +3 and -2 while the degrees of China's water security cooperation with other South Asian countries remain between +3 and 0 .

In short, there is no significant problem on water security between China and ten of its neighboring countries, but disputes exist between China and other seven countries. In general, water security cooperation between China and its neighboring countries can be characterized by "lowconflict and low-cooperation." 


\section{Determinants of China's Water Security Cooperation with its Neighboring Countries}

There are four major determinants in the current cooperation on water security between China and its neighboring countries:

\section{Water Scarcity and Reliance on Trans-Boundary Water Resources}

Water scarcity is a common problem that both China and its neighboring countries are facing. In particular, some countries are highly dependent on external water resources and thus more vulnerable to the changes of water quantity in relevant rivers (see Table 3). Statistics show that the annual water availability for India, Kazakhstan and North Korea are all below $1700 \mathrm{~m}^{3}$. Though Bangladesh, Cambodia, Thailand and Vietnam are rich in water resources; their dependence on external water also exceeds 40 percent. Therefore, these countries are sensitive to the water utilization of other basin countries. Besides, due to their relatively low level of development, these countries are more cooperative on water security issues with other countries.

Table 3. Water Resource Availability for China and its Neighbors.

\begin{tabular}{lccc}
\hline Country & $\begin{array}{c}\text { Annual Renewable } \\
\text { Water Resource }\left(\mathrm{km}^{3} / \mathrm{yr}\right)\end{array}$ & $\begin{array}{c}\text { Annual Water Resource } \\
\text { Availability }\left(\mathrm{m}^{3} / \mathrm{p} / \mathrm{yr}\right)\end{array}$ & $\begin{array}{c}\text { External } \\
\text { Dependence (\%) }\end{array}$ \\
\hline Afghanistan & 65.3 & $2,242.4$ & 15 \\
Bangladesh & $1,127.0$ & $8,651.8$ & 91 \\
Bhutan & 78.0 & $109,859.2$ & - \\
Cambodia & 476.1 & $31,634.5$ & 75 \\
China & $2,738.8$ & $2,011.2$ & 1 \\
India & $1,900.0$ & $1,573.5$ & 34 \\
North Korea & 69.7 & $1,437.1$ & - \\
Laos & 333.6 & $51,801.2$ & 0 \\
Mongolia & 34.8 & $12,888.9$ & 16 \\
Burma & $1,168.0$ & $23,128.7$ & 6 \\
Nepal & 210.2 & $7,041.9$ & 49 \\
Thailand & 438.6 & $6,436.7$ & 59 \\
Vietnam & 884.0 & $9,929.2$ & - \\
Russia & 4508 & - & - \\
Tajikistan & 21.9 & $3,097.6$ & - \\
Turkmenistan & 24.8 & $4,787.6$ & - \\
Kazakhstan & 107.5 & - & 77 \\
Kyrgyzstan & 23.6 & $4,252.3$ & -759.6 \\
Uzbekistan & 48.9 & $1,759.6$ & \\
\hline
\end{tabular}

Source: The World's Water, http://worldwater.org/. 
Table 4. Overall Relationships Between China and its Neighbors.

\begin{tabular}{ll}
\hline Bilateral Relations & Country \\
\hline Comprehensive strategic coordination partnership & Russia \\
Comprehensive strategic partnership & Kazakhstan, Mongolia \\
Comprehensive cooperative partnership & Nepal, Bangladesh \\
Comprehensive strategic cooperative partnership & $\begin{array}{c}\text { Thailand, Vietnam, Cambodia, Laos, } \\
\text { Burma }\end{array}$ \\
Strategic cooperative partnership & Afghanistan, India \\
\hline
\end{tabular}

Source: www.fmprc.gov.cn.

\section{Lack of Strategic Trust Despite Positive Relations at the State Level}

As can be seen from Table 4, China maintains positive relations with peripheral countries in general. Among the 19 neighboring countries (including its maritime neighbors), China has built various partnerships with 11, which determines the low-conflict status of their water security cooperation. The level of water security cooperation will deepen with further development of the overall relationships among these countries. Strategic partnerships between China and some of its neighboring countries have demonstrated the fundamental rules of solving bilateral problems through coordination and cooperation.

Nevertheless, it is noteworthy that lack of strategic trust affects China's interactions with its neighboring countries. Some historic memories from the 1962 China-India border conflict, as well as the decade-long war between China and Vietnam, have fueled this kind of distrust. At present, China still has some territorial disputes with India and Vietnam. Since China's rapid economic development has strengthened its national power, many neighboring countries think of China as a strategic competitor or potential rival in political and military terms, which inevitably has some impact on water security.

In recent years, India has reacted strongly to China's water exploitation in some trans-boundary rivers, and regarded China's behavior as a security threat or even "strategic containment." India's perspective on the construction and operation of the international community is largely shaped by its experiences of historical catastrophe and foreign invasion ${ }^{6}$, increasing its sensitivity to actions by other countries. The 1962 China-India Border War,

${ }^{6}$ J. J. Dixit, India's Foreign Policy and its Neighboring Countries (New Delhi: Gyan Publishing House, 2001), p. 22. 
for instance, has led to India's misunderstanding of China fundamentally. Right after the border war, China began to be perceived as a country intent on implementing expansive and invasive policies that threatened India's national security. In the eyes of India, China seeks great power status and is thus also a competitor for India's rise to be a great power. From the Indian perspective, as a developing country with rapid economic growth, China has huge demand for natural resources, especially for water resources, based on its own geographical advantages. Thus, China can also be a potential competitor for India in terms of water exploitation.

To some extent, lack of strategic trust is a major reason that prevents China and its neighboring countries from achieving substantive cooperation. Now, most of the water security cooperation still remains at a primary level, such as signing bilateral agreements, conducting mutual dialogues, and setting agendas in regional cooperative frameworks. The context of cooperation mainly focuses on sharing information within a certain period of time, but fails to deal with some key issues such as water allocation.

\section{Divergent Expectations for Water Exploitation and Utilization}

Due to the disputes, even conflicts, over water resources on China's peripheries, water security has become an indispensable pillar of regional stability. In South Asia, different countries (even political factions, religions, and races) have long histories of animosity and territorial dispute. These countries tend to adopt a confrontational attitude and take unilateral actions when there are water disputes, thus leading to conflicts that destabilize the region. Among India, Pakistan, Bangladesh, and Nepal, issues related to water allocation and exploitation persist all the time. When dealing with water issues, India prefers mighty diplomacy, protesting that China's construction activities on the Yarlung Zangbo River and the exploitation of the Brahmaputra River flowing through southern Tibet have undermined India's water security. Therefore, water security issues are usually intertwined with territorial disputes between China and India. The bilateral relationship and the special geopolitical circumstances have determined a limit of cooperation and the inevitability of conflicts.

In Central Asia, water is more expensive than oil. After the collapse of the Soviet Union, the five Central Asian Republics declared their independence. Against this backdrop, water issues that had previously been hidden behind the central planning water allocation mechanism finally 
emerged, and before long the five Republics found themselves in a "water resource dilemma." All these countries regard water resources as part of their core national interests, considering water disputes as a "zero-sum game" and thus try their best to expand control over water resources. In the past two decades, these Central Asian countries have yet to successfully reach an agreement on water allocation or agree to any official consumption quotas. The water disputes have thus continued ever since. In Central Asia, more than two-thirds of surface water is distributed in the upstream countries, typically Tajikistan and Kyrgyzstan. More than half of the water flow (55.49 percent) and more than 60 percent of glaciers are in Tajikistan, ${ }^{7}$ while the surface water in Uzbekistan, Kazakhstan, and Turkmenistan just account for 42.5 percent of the total amount. Water is in short supply in these three countries which depend on inbound water flow. Water demands from these three countries are huge, especially in Kazakhstan. The Balkhash Lake has been shrinking since 1970 because of reduced surface water runoff and strong evaporation, affecting the ecological system at the estuary delta. In this light, Kazakhstan pays more attention to the sustainability and maintenance of water quantity. In this geopolitical environment, solving problems concerning water resource allocation and maintaining the adequate runoff of the Irtysh River and Ili River into Kazakhstan have gradually become the core of China-Kazakhstan cooperation on water security.

In Southeast Asia, especially in the Mekong River Basin, abundant water resources are nature's gift to the large population. However, these resources have not yet been well-exploited due to lack of technology and financial support, with power shortages continuing to be common in the region. In the past years, Chinese companies have acquired rich experience in hydropower development and management and have developed professional and technical expertise with regard to local ecology, water flow, and geologic structure, even as international financial institutions and some Western governments are cautious about investing in hydropower projects. In order to meet their economic and social needs, the Mekong River countries tend to cooperate with China to develop water resources.

The Lancang-Mekong River is the major river running through the Mekong River Basin, while the five countries along the river have divergent

\footnotetext{
${ }^{7}$ Xu Xiaotian, "Zhongya Shuiziyuan de Kunju [The Predicament of Central-Asia Water Resources]," World Affairs, No. 20 (2010), p. 40.
} 
expectations about how to exploit the water. China's activities with regard to the Lancang River are basically for hydroelectric generation. China has planned to build eight cascade hydropower stations. Burma focuses on the construction of river lanes for convenient navigation. The aim of Thailand and Vietnam is to improve agricultural irrigation, while the attention of Laos is also focused on hydroelectric generation which could be a new source of foreign exchange income through electricity exports. Cambodia seeks to further develop fishery. Based on these various expectations, the Mekong countries are concerned that China's dam building activities upstream will lead to water flow shrinkage, which might cause ecological and environmental problems and thus affect the agricultural and fishery sectors in downstream countries.

\section{Lack of an Effective Water Management System and a Unified Trans-Boundary Water Security Strategy in China}

China's water management authorities include the Ministry of Water Resources, river basin agencies, and local water administrations. Generally speaking, the water management system is characterized by a combination of ownership and purpose management, a combination of unified and classified management, and the combination of river basin and administrative management. ${ }^{8}$ However, in terms of trans-boundary water management, China has not yet built a unified water security strategy. Water cooperation between China and its neighboring countries lacks design from the top level. Scientific research with regard to the development and exploitation of water resources has yet to be emphasized at the strategic level, which could guide China's neighboring diplomacy.

The current water management system in China generally involves over a dozen governmental agencies or departments, whose functions overlap with decentralized powers, making it difficult to coordinate

${ }^{8}$ Wang Guanjun, Wang Chunyuan, and Feng Yunfei, “Zhongguo Shuiziyuan Guanli he Touzi Zhengce [China's Policy for Water Resource Management and Investment]," Water Resource Development Research, No. 5 (2001), p. 1. 
Table 5. China's Institutional Involvement in the Water Management System.

\begin{tabular}{|c|c|}
\hline Institution & Main Function \\
\hline $\begin{array}{l}\text { National Leading Group for } \\
\text { Water Resources and Conser- } \\
\text { vation of Water and Soil }\end{array}$ & Integrated planning for water resources in basins/areas \\
\hline Ministry of Water Resources & $\begin{array}{l}\text { Unified management of national water resources, } \\
\text { mainly including surface water management }\end{array}$ \\
\hline $\begin{array}{l}\text { Ministry of Environmental Pro- } \\
\text { tection }\end{array}$ & Environmental protection of water areas \\
\hline Ministry of Agriculture & Agricultural water management \\
\hline National Energy Administration & Hydropower development and management \\
\hline Forestry Bureau & Basin forestry water and resource protection \\
\hline $\begin{array}{l}\text { Ministry of Housing and Urban- } \\
\text { rural Development }\end{array}$ & $\begin{array}{l}\text { Urban water resources development and protection } \\
\text { construction }\end{array}$ \\
\hline Ministry of Land and Resources & $\begin{array}{l}\text { Groundwater management, project management in } \\
\text { basins protection, sea water management }\end{array}$ \\
\hline $\begin{array}{l}\text { National Development and Re- } \\
\text { form Commission }\end{array}$ & Approval of water resources projects \\
\hline Ministry of Transport & River shipping management \\
\hline $\begin{array}{l}\text { National Health and Family } \\
\text { Planning Commission }\end{array}$ & $\begin{array}{l}\text { Monitoring and protection of resident daily drinking } \\
\text { water }\end{array}$ \\
\hline Ministry of Finance & Approval of flood control funds \\
\hline $\begin{array}{l}\text { China Meteorological Adminis- } \\
\text { tration }\end{array}$ & Atmospheric precipitation forecast and management \\
\hline $\begin{array}{l}\text { Ministry of Science and Technol- } \\
\text { ogy }\end{array}$ & Scientific research and management of water resources \\
\hline
\end{tabular}

Source: China's State Council website, http://www.gov.cn/guowuyuan/.

inter-agency actions or policies and further resulting in low working efficiency (see Table 5). For example, the Ministry of Environmental Protection and the Ministry of Water Resources face difficulties in coordinating the management of water yield and water quality. The Ministry of Environmental Protection usually pays attention to water quality protection, while the Ministry of Water Resources focuses on total water supply, water utilization and allocation, engineering and construction of hydropower projects. However, it ignores the protection of ecology and water quality, and the control of water demand. In short, China has not yet established a centralized and unified system for trans-boundary river management, and there is no single authority to coordinate across different sectors such as agriculture, industry, urban, hydropower generation and ecology.

Though the ownership of water resources is sole, the rights to use water are not limited. The definitions of responsibility, authority, and 
benefits are complex, and the decisions are always inconsistent. Information is not shared, which leads to poor management of water resources, in which the right of water utilization is muddy between upstream and downstream regions, also among different departments or water faculties within the same country. The discord of water management involves urban and rural water utilization, pollution prevention, flood control, disaster reduction, and ecological and environmental protection. Buck-passing behaviors are prevalent, and issues of water scarcity and water waste always coexist. Water pollution and environmental damages are chronic problems. The peculiarity and disadvantage of China's water management system are not only the source of disputes between China and its neighboring countries, but they also restrict the deepening of the water security cooperation.

\section{Reactions of China's Neighboring Countries}

The nature of the trans-boundary rivers has determined that China and its neighboring countries are naturally interdependent. However, such interdependence is asymmetrical due to various geographical conditions and degrees of dependence by countries. Compared with its neighboring countries, China welds stronger economic power and geographically occupies the upstream of many trans-boundary rivers. This is why China is called the "Water Tower in Asia." Since many of China's neighboring countries are dependent on trans-boundary rivers, they are very sensitive and vulnerable to the water quality and quantity in these rivers. Therefore, the water security cooperation between China and its neighboring countries is a kind of asymmetrical interdependence, which accords China much "water power."

In the low-conflict and low-cooperation structure of water security relationships, such potential "water power" has created different political meanings for China and its neighboring countries and triggered different reactions. For the neighboring countries, China's "water power" makes them vulnerable to water insecurity, and thus they feel it necessary to confront

China's neighbors are trying every means to confront the perceived "water power." China so as to improve their positions in the asymmetrical power structure. As a result, some neighboring countries of China have begun their coordination with some extraterritorial countries to contain the "water power" of China. 
First, although the International Water Law has provided the guiding principles for the utilization of trans-boundary water resources, the international community has not established a unified legal regime for transboundary water management. China has yet to join the Convention on the Law of Non-navigational Uses of International Watercourse, for its many provisions are potentially against the upstream countries, imposing many restrictions on China's exploitation on trans-boundary water. China is currently one of the three countries that have voted against the Convention while all its neighbors have joined it.

Second, China's neighboring countries always intentionally oppose China's legitimate rights and obligations. On one hand, they build bilateral mechanisms to confront China in terms of information sharing, pollution prevention, and water utilization; on the other hand, they attempt to involve China in the regional mechanisms that could put China under restriction. One example is the Mekong River Commission (MRC), which tries hard to "invite" China to join. However, in the eyes of China, 80 percent of the MRC's funds come from Western countries' assistance. The motivations of Western donations need to be considered, in order to guarantee the interest of the Mekong River Basin countries. When a country joins as a member of the MRC, it must share information on hydroelectricity, which is regarded by China as a sensitive problem. ${ }^{9}$

Third, China's neighboring countries always attempt to occupy the high ground of water rule-making with the aid of extraterritorial countries. For instance, the European Union has intervened in the water management on China's peripheries. On one hand, they integrate water issues into key cooperation areas, and make huge investments in improving the water management of China's neighboring countries; on the other hand, they advocate for the European model and the formulation of water laws. It is noteworthy that Central Asia and the Mekong River Basin in Southeast Asia are two regional priorities of EU actions. From 2009 to 2012, the EU has allocated 1.5 million Euros for sustainable and effective water management programs in Central Asia; from 2012 to 2015, the EU set up the environmental program of Central Asia, aiming at further promotion of

\footnotetext{
${ }^{9}$ He Daming and Fengyan, Guoji Heliu Kuajing Shuiziyuan Heli Liyong yu Xietiao Guanli [Reasonable International River Water Utilization and Coordination Management] (Beijing: Science Press, 2006), p. 163.
} 
regional cooperation and partnership building efforts in the trans-boundary water management between EU and Central Asian countries, which include experience sharing and educating water professionals and senior talents. ${ }^{10}$

In the Mekong River Basin, the EU Committee has announced an aid of 4.95 million Euros to the MRC, to help tackle the climate-driven floods and other problems. ${ }^{11}$ Now, the EU regards water security cooperation as a key field in the framework of Asia-Europe Meeting (ASE) and the Association of Southeast Asian Nations (ASEAN). ${ }^{12}$

Meanwhile, the EU endeavors to carry out its own management model. In the Mekong River Basin, the EU makes great efforts to push for integrated water management in Asia and strengthen the construction of organizational structure. Germany once provided funds to support the building of the MRC comprehensive information system. River basin countries can thus share their information and achieve integrated management. In some documents, such as the EU Water Framework Directive (WFD), and the Environment and Water Initiative of EU and Central Asia, the EU emphasizes strengthening global water resource coordination and management efficiency, in order to gain power of discourse on rule-making regarding water issues.

\section{Toward Better Cooperation on Water Security}

From the strategic perspective, promoting water security relationship is in China's national interest. In the long run, the low-conflict and low-cooperation structure of water security will undermine China's efforts to build sound relations with neighboring countries, especially against the backdrop

${ }^{10}$ See the European Union Regional Environment Program for Central Asia at http://ec. europa.eu/europeaid/node/1337_en.

11 “The European Union Provides over 6 Million USD to Tackle Climate Change in the Mekong," European External Action Service website, January 18, 2013, http://eeas.europa. eu/delegations/laos/press_corner/all_news/news/2013/20130116_en.htm.

${ }^{12}$ Gerhard Sabathil, “Europe-Asia Dialogue on Water Management Policies Overview of Possible Future Common Action," Speech at the Third ASEM Sustainable Development Seminar on Water Management, http://eeas.europa.eu/asem/docs/20140602_speech_sabathil_ final_en.pdf. 
of climate change. Therefore, how to foster water security cooperation is an important topic for discussion.

With the mounting water crisis in Asia, China as a responsible regional power should play a leading role in promoting water security, introducing "cooperative management" as the core context and "basin + region" as the framework. The key to achieving water security is to adopt cooperative management. China is working with its neighboring countries to organize, coordinate, supervise, and mediate water utilization and protection, in order to make full use of the water resources in a fair, rational, and effective way.

On China's peripheries, there exist many regional frameworks of cooperation. China could add water governance issues into current frameworks, and then construct new mechanisms of coordination, which will not only focus on one specific topic, but also broaden the context and depth of cooperation. With regard to the basin management, China needs to promote comprehensive management from four dimensions including cooperation goal, cooperation participation, cooperation activity, and cooperation mechanism. For cooperation goal, progress is to be made from preventing and solving conflicts to striving for and expanding common interests, and then to sustainable development of the river basin. For cooperation participation, efforts must be taken from bilateral to multilateral levels, and from parts to the entirety of the river basin, and then to an even broader scope. For cooperation activity, unilateral actions need to be upgraded into bilateral exchange (information sharing, technology exchange, knowledge forum, and so on), and then further into negotiation (notification and consultation, analysis and research, memorandum signing) and coordination (policy/plan/project/activity adjustment of individual country). For cooperation mechanism, more mechanisms with ever stronger authority and constraining force should be established involving different levels and areas, so as to enhance cooperation. ${ }^{13}$

As an upstream country, China has stronger economic power and technological capability than downstream countries. When China

${ }^{13} \mathrm{Hu}$ Wenjun, JianYinghui, and Yang Jianji, “Guoji Heliu Guanli Hezuo Moshi de Fenlei ji Yanjin Guilü Yantao [Exploring the Classification and Evolving Principles of the Cooperation Models in International River Management]," Journal of Natural Resources, Vol. 28, No. 12 (2013), p. 2039. 
vigorously develops the trans-boundary water resources, it should give more consideration to the interests of downstream countries and help them benefit from relevant projects. For example, China should export some electricity to downstream countries and pay close attention to their water quality and quantity demands. Many countries think that China's exploitation of water resources will bring negative effects to the ecological system, the environment, and even human rights, especially when those dambuilding activities on trans-boundary rivers may destroy eco-system and biological diversity, let alone the lifestyles of local people - villagers are forced to leave, with no compensation, losing their homes, land, and livelihoods. ${ }^{14}$ To reduce such negative social impact and international pressure, as well as improve China's international image, the central or local governments should provide special funds for ecological and immigrant compensation.

Since trans-boundary water disputes are extremely complicated, the basin countries need to establish a robust mechanism for dispute settlement, which includes means of dispute resolution, principles as well as dispute settlement body. ${ }^{15}$ Nowadays, mechanisms for trans-boundary water dispute settlement are included in very limited international treaties,

China should take the lead in enhancing management and cooperation of the region on water resources. bilateral environmental, and border treaties. The provisions for dispute resolution are impractical, being inefficient and inconsistent with the international trend of regularization and legislation. ${ }^{16}$

At the current stage, trans-boundary water disputes could be solved mainly via political and legal means. The political means refer to negotiation, coordination, mediation, investigation and reconciliation through diplomatic channels; while the legal way is by arbitration and even lawsuits

14 “Jiankang de Heliu, Xingfu de Linju [Healthy Rivers and Happy Neighbors]," Burma Rivers Network, http://burmariversnetwork.org/chinese/images/stories/publications/chinese/healthyrivers.pdf.

${ }^{15}$ Jia Lin, Guoji Heliu Zhengduan Jiejue Jizhi Yanjiu [International River Dispute Settlement Mechanism] (Beijing: Intellectual Property Press, 2014), p. 146.

${ }^{16}$ Ibid., p. 219. 
through the judicial procedure of international courts, based on relevant conventions, laws and some general rules or principles.

In the future, China should improve the mechanisms for dispute settlement of the water disputes on its peripheries. First, China should continue to use negotiation and coordination as the major means to settle water disputes. In bilateral water security cooperation, China should learn from successful cases in the international community and try to develop a flexible negotiation and coordination procedure. Second, China should encourage some inter-governmental organizations to pioneer in settling disputes, such as the China-Kazakhstan Trans-boundary River Commission. The bilateral joint commission could keep the stability and sustainability of the platform as well as the framework of negotiation and coordination, ensuring the smooth functioning of the information exchange and decision-making systems. Third, China should introduce certain legal methods. The international community always promotes legal procedures in order to decrease the power orientation of politics, economy and military. However, through legal solution of water disputes, China could face unfavorable situations while developing its transboundary water resources. In this sense, China should try to solve water disputes by employing legal methods in a selective way. Fourth, China should involve social organizations in the negotiation and coordination process regarding water disputes. China could create a better climate for homegrown NGOs and make them a "helping hand" for the government. These NGOs could improve the public perception in China's neighboring countries through flexible social engagement. The NGOs might play the role of "ice-breakers" when inter-governmental negotiations fall into a deadlock.

\section{Conclusion}

Good peripheral relationships are the strategic basis for China's national rejuvenation. Against the background of climate change, water security cooperation has gradually become one of the key topics between China and its neighboring countries. China should, on one hand, cooperate actively with neighboring countries to reduce tensions caused by climate change, and, on the other hand, take immediate actions to formulate a water security strategy, seeking more voice in the rule-setting process and turning 
its own strategic advantage on water resources into a common ground of building stable neighboring relations.

Furthermore, China should launch a water diplomacy campaign characterized by strategic partnership construction and public diplomacy, making water diplomacy a shining chapter in conflict prevention, crisis management, and regional cooperation. With respect to conflict prevention, China should make efforts to address the root cause of water conflicts and incorporate conflict prevention into its international development and cooperation agenda, as well as foreign aid policy. Regarding crisis management, China should maintain its advantage on rapid involvement and effective containment, which includes easing disputes, initiating discussion and coordination, and rebuilding friendship. ${ }^{17}$ With regard to enhancing regional cooperation, China should maintain regular dialogues with its neighbors and seek new opportunities from their cooperation in water security to develop its foreign relations.

${ }^{17}$ Li Zhifei, “Shuiziyuan Waijiao: Zhongguo Zhoubian Guanxi Goujian Xinyiti [Water Diplomacy: New Topic of China's Periphery Relations Construction]," Academic Exploration, No. 3 (2013), pp. 33-34. 